\title{
THE USE OF DISCOURSE IN THE MANAGEMENT OF BLAME IN CONFLICT SITUATIONS: THE CASE OF KENYA'S INTERNALLY DISPLACED PERSONS
}

\author{
Nelson Ndiritu ${ }^{*} 1$ 不 \\ ${ }^{* 1}$ Laikipia University, Kenya
}

DOI: https://doi.org/10.29121/granthaalayah.v8.i7.2020.572

Article Type: Case Study

Article Citation: Nelson Ndiritu. (2020). THE USE OF DISCOURSE IN THE MANAGEMENT OF BLAME IN CONFLICT SITUATIONS: THE CASE OF KENYA'S INTERNALLY

DISPLACED PERSONS. International Journal of Research -

GRANTHAALAYAH, 8(7), 179-184. https://doi.org/10.29121/granthaa layah.v8.i7.2020.572

Received Date: 23 June 2020

Accepted Date: 30 July 2020

Keywords:

Management

Kenya's Internally

Displaced Persons

\section{ABSTRACT}

The use of violence as means of addressing differences between groups and individuals is common. The world has witnessed wars and small-scale violence resulting from disagreements. Violence however leaves behind trails of destruction and pain in its wake. It also generally perceived as a sign of failure of the power of the intellect to address issues. It is therefore regarded as a primitive method which is employed as a last resort.

Parties that have been involved in violence may therefore find need to explain the reasons for their involvement and often tend to lay blame for the violence elsewhere. This paper investigates the discursive resources employed in the management of blame in conflict situations taking the case of the Kenyan Internally Displaced Persons.

The paper employs Discursive Psychology one of the approaches to discourse analysis to investigate the management of the blame arising from the violence that followed Kenya's 2007 elections. The paper draws from a research carried out by the author among 24 Internally Displaced Persons in Kenya's 2007/2008 post-election violence. The research sample comprised an equal number of male and female respondents who were from the different communities involved in the violence.The data was collected by means of in-depth interviews.

\section{INTRODUCTION}

Violence between different ethnic communities in Kenya can be traced back to the pre-colonial period. The Akiwumi report (1999) says that before colonialism in Kenya, the Rift Valley which is a common flashpoint of the violence was occupied mainly by the Kalenjin, the Maasai, the Turkana, the Samburu, the Pokot and sections of the Luhya and they held land communally. The pressure on land was not as great as it is today but even so, inter-clanal and sometimes inter-tribal conflict was not uncommon. According to Yieke (2010), the violence was however, never of the large-scale type.

In the post-colonial period, from 1963, inter-ethnic violence only became common with the introduction of multiparty politics in 1992. From that time the country has experienced inter-ethnic violence in the run up to almost every election. The violence often takes the form of armed attack on an ethnic community by another community and leads to destruction of property, injuries, death and displacement.

The 2007 post-election violence exhibited dynamics that were more like a civil war than the previous occurrences of violence (Klopp et al, 2010). It was unprecedented in a country that had been hailed as a beacon of

(C) 2020 The Author(s). This is an open access article distributed under the terms of the Creative Commons Attribution License, which permits unrestricted use, distribution, and reproduction in any medium, provided the original author and source are credited. 
peace in Africa (Gutiérrez-Romero, 2010 and Kamenyi \& Ndung'u, n.d). The violence has been described as the the 'worst crisis since independence' (Matheson, undated:1) whose 'magnitude and spread was far much greater than what was experienced in the previous elections' (Kanyinga, Okello and Akech 2010:14). In the 2007-2008 postelection violence, it is estimated that 1,162 people died, 350,000 were displaced and according to CIPEV (2008) report, 3,561 people suffered injuries. There were many cases of rape (Aura, 2010) which Roberts (2009) puts at 3,000 affecting mainly women and children and a few affecting men. Similarly, 117,216 private properties and 491 government properties were destroyed. About 32 percent of 2007 IDPs interviewed in a research carried out by United States Institute for Peace had been affected at least once before (Klopp et al, 2010).

\section{THEORETICAL FRAMEWORK}

To carry out investigation on how the displaced persons handle the issue of blame and responsibility for the violence Discursive Psychology will be employed. Discursive Psychology (DP) is a kind of discourse analysis that was formulated by Edward and Potter in 1992. It has been defined as the application of principles and methods from discourse and conversation analysis, and increasingly CA, to psychological themes (Edwards,in Fitch and Sanders, 2005). Its focus is on how actions such as attribution of blame and responsibility, praising, defending are done and avoided indirectly in discourse and the way psychological terms are employed in everyday talk.

The way of talking gives certain nature of events among many possible versions. The versions are carefully crafted to perform certain actions. A particular version of events may, for instance, perform the action of blaming a certain person for an occurrence.

DP also takes the position that some psychological terms are used in common discourse to construct the nature and explores the working of common-sense psychological terms or thesaurus. These are terms that are conventionally used in cognitive psychology and which ordinary discourse also employs. They include words for emotional and mental states such as angry, upset remember, think, , jealous, know ,believe ,feel and want among others as well as a range of available idiomatic and metaphorical constructions like bear in mind, boiling, raged and so on.

DP investigates how as part of respecification, people present events without overt description of motive but the presentation is calculated to handle such issues as agency and attribution. In this way people are able to avoid blame for things that have gone wrong and to attribute them to others. According to DP this is management of psychological issues even if people do not necessarily term them psychological.

DP looks at how people describe events with the intention of blaming or challenging blame. In this way, DP shows that speakers do not merely give descriptions; they describe while attributing. Engaging in discourse in DP is therefore engaging in actions such as praising, defending and blaming among others.

Discourse is constructive of different versions of the world, including versions of actions, events, histories, social structures organizations, psychological characteristics and phenomenological experiences. DP studies both the actions done with these constructions and the way these constructions are built to be stable, objective and independent of the speaker.

The paper will analyse the discourse of the displaced persons under the following topics.

\section{LACK OF PRIOR KNOWLEDGE AND MOTIVE}

The interviewer would ask the respondents what happened with the effect of displacing them. in response, the displaced persons narrated the events leading up to the violence often starting from the voting day. Their narratives generally bespoke a total lack of knowledge of the possibility of violence following the voting. Some of the transcripts are as the following:

\section{Excerpt 1}

R: Saa: hiyo mwaka kukawa na: kura inapigwa /ya:kuchagua mapresident / saa tukaendelea/tukapiga kura/wakati ilifika/ilipo-ikafika na wakati wa matangazo nani mshindi/baadala ya kusikia mshidi ilitangaza na baadaye kukawa na mlipuko na vita ikaanza/ kila mtu akawa katika harakati ya kutoroka hapa na pale kujiokoa/

I: Sasa nyinyi mlitoroka? 
Nelson Ndiritu

R: Ee ilibidi sababu kwenye tulikuwa ndio kulikuwa kubaya sana/

I: Area gani?

R: Ilikuwa area ya: Nakuru/ kulikwa Nakuru mahali panaitwa(XXX)

R: That time: in the year there was: voting was done / to elect a presidents/ then we proceeded/ we voted/ when it was time/ when it was time for announcement of the winner/ instead of announcing the winner it was announced and there was an explosion as violence started /everyone made efforts to flee here and there to safe themselves/

I: Did you then run away?

$\mathrm{R}$ : Yes we had to because where we were was a hot spot/

I: Which area?

R: It was in the area of: Nakuru/it was in Nakuru a place called (XXX) (TR19 P1)

The respondent says that in that year, 2007 there was an election. She presents this as something that came to her like to everyone else and as a normal exercise in its ordinary season in the country's political cycle. The voting was therefore not brought about by her own or her ethnic community's effort. She says that on her part she voted for there was voting and waited for the results of the elections to be announced only to receive news of violence. She participated as any other dutiful person but violence followed the elections. Her voting did not therefore have anything to do with the violence to the best of her understanding. She therefore comes out as having been taken by surprise by the eruption of the violence.

Another respondent TR2 an elderly lady of 78 years places her voting like that of the other members of her ethnic community, in a long tradition of civic participation in governance. She explains as follows:

\section{Excerpt 2}

$R$ [...] No ni turigagwo ni kii giacokere gi githii na mbere/ hindi io riu ya githuano/ na ni waigua korwo mundu ni ari na kiroto/ ndui kura icio tutingiaciakirie korwo nitwamenyaga nicio ikurehe rumena . No tondu ni kawandari , tuturite tucikitieri na nginya ihindi ya Kenyatta no twamuthirireri/ na twamuthirire ona kura iciri tutionaga ta kuri undu ungiuka tuhone ni twai ni twanena. Riu twaki ona githurano giatengathwo tutiakoriwo twin a kiria no uria andu magikenagirira /XXX/ na ni twonaga githithi kiao to kiega.

I: To kiega.

$\mathrm{R}$ [...] But we wonder what then happened/ during the elections/ and you know if one had had a premonition we would not have cast those ballots/ if only we knew that they were the ones that would bring hatred. But it is normal that we have always cast our ballots even during the Kenyatta era, we voted for him and we voted for him using the same ballots so we were not anticipating any kind of enmity between us to come out of it. Now when we saw the election results announced we had no whatever its just how people celebrate/ but we could see their faces were not happy (TR2 P1).

She says that she like the other had voted for Kenyatta, the first president of Kenya using the same ballots and no violence had resulted. Kenyatta led Kenya from 1963 to 1978. The respondent had therefore voted over period of about 43 by 2007 without experiencing violence and she therefore did not expect any violence to follow her voting. The respondent explains that they did not understand how the violence came about as a result of the elections. The respondent further justifies her position arguing that had they any premonition of violence following the elections, they would have abstained from voting. This means that they would have foregone their democratic right to participate in the election to avoid violence. The respondent is not in any way responding to a question on whether they caused the violence but is only describing the events. The description however takes the form of blame attribution which has the effect of saying that she was totally innocent.

To illustrate the innocence of the displaced persons another respondent explained that they were all set for the end of year festivities when violence broke out. TR9 a young lady who was then about sixteen years put her experience as follows:

\section{Excerpt 3}

R: [...] kwa familia zingine. Huyu anatoka uchagu huko anakuja hapa, sasa kuna kuku zimechinjwa / mbuzi, kondoo na venye tunabelieve tarehe kama hiyo / tunakula (laugh) sasa tulikuwa tumejitayarisha tu vizuri /. Na hatukujua kama wanakuja / sisi tulikuwa tu tumelala, sasa redio inawaka 
I: e

R: kidogo tunasikia makelele hama na hayo ni makelele ya? Krismas. But kuangalia sasa maybe mamilima, kunaona ma moto nini /. Kupigapiga simu huko juu ati sijui Wamarakwet wanatufamia / hawasemi wanataka nini / ikabidi tu more / majirani kukutana hao watu wazima kuanza maybe kuomba /. Tukaomba, lakini hatukufua dafu.

R: [...]For some families Some come from reserve to this place, now there are slaughtered chicken, goats, sheep, and what we believe on such a date we eat (laughs) now we had prepared ourselves well and we didn't know if they were coming. As for we were just asleep, now the radio is on a low volume

I:e

R: Then we get to hear noise, like the noise about? Christmas. But on looking now maybe there at the hills we saw fire, what is it?, we make some calls there; it's about. I don't know that the Markwet are attacking us, they are not saying what they want. We had to move, meeting the neighbors the adults started may be to pray. We prayed but all in vain. TR9 Pg 2-3

According to the respondent her community did not have any inkling about violence. They did not even have reason to expect such violence. Their celebratory mood explains it all. They knew no one who had an issue with them that could cause violence. When they therefore heard that they were under attack they could did not know what the attackers wanted.

\section{NOT ARMED}

The respondents also cited the fact that their assailants came with sophisticated weapons and were in large numbers to explain the fact that the assailants easily overcame them.

TR1 an elderly man from the Abagusii community explains this as follows;

\section{Excerpt 4}

R: Walikuwa na vitu nyingi/sio ma ninii pekee yake/walikuwa hata na mabunduki /

Walikuwa napigwa mpaka watu katetemeka/ Hata sasa/ uwanaume ukakwisha tukakuwa kama vitu ingine/ hatuna ninii.

$R$ : They had a lot of things/ not just the doings only/they had even guns/ They would shoot till people would shake/To a point our/our manhood was finished/We were just like other things/without whatever.

I: Hamkuwa wanaume?

I: You were not men?

$\mathrm{R}: \mathrm{Ee} / \mathrm{Ee}$

R: Yes/Yes

I: Sasa mlikuwa mnajisikia namna gani?

I: How did you feel?

R: Sasa tulikuwa tuna- na uoga tu/hata unakimbia hujui unaenda wapi. /tukawacha kila kitu

R: Now we had fear/ then you would run not knowing where you were going/ we left everything (TR1P3).

The elderly man explains that the attackers were heavily armed in his description that they had many things and goes ahead to name some of the weapons as guns. The guns were also used to shoot to a point where the displaced persons would shake. The displaced persons did not know of the planned attack. Gun ownership and handling is controlled very strictly in Kenya. It is only the police the army and other uniformed groups that carry and use guns. For private citizens only a few are licensed to carry guns who number around 10,000 in a country of about forty million (Mukinda, 2016). These have to adhere to very stringent conditions including reporting to the police any discharge of a bullet from the gun in their possession (Mukinda 2016) The fact that the attackers wielded guns while the displaced could only brandish machetes means that the displaced persons were completely outgunned. This puts the displaced persons in a very miserable position in the combat and explains why they lost so heavily.

The explanation that when the shots rung men lost their manhood means they were no longer able to stand up to their assailants as men would in a combat. The men then become 'other things' and not men for the situation was 
Nelson Ndiritu

well beyond their power to manouvre. This explains why they had to run. They cannot therefore be blamed when these are taken into account.

\section{YOUTHFULNESS}

There was a respondent who was about fourteen years when the attacks happened and he explains that he was too young to resist the attackers. He described the situation as follows:

\section{Excerpt 5}

R: Yanachomwa mpaka mchana /mpaka usiku / vile nililala kachibora asubuhi yake tulienda kuchungulia kama kuna kitu/ tukaona hatuwezi chukua. Ee

R: They would be burned even during the day/ and even at night / I spent the night at Kachibora/ the following day in the morning/ we went to check whether there was anything left / and we found that we could not take anything.Yes

I: Sawa sawa. Halafu, sasa ukiona hayo ulikuwa unafanya nini?

I: Alright then when you would see this what would you do?

R: Wakati huo?

R: At that time?

I: Ee.

I: Yes.

R: Wakati huo ndio nilikuwa standard seven / nilikuwa 183ub ado mimi ni mwanafunzi

R: That was when I was in grade seven/ I was still a pupil (TR8P1)

The respondent when asked what he did in the face of the attacks and the attendant loss of property says he was only in grade seven. This is his way of saying that he was not yet a grown up. Grade seven pupils are usually around thirteen years old and by implication, he was too young to effectively tackle the attackers. He cannot therefore have been comparable to the attackers and was not expected to engage them. The respondent does not think it would have been wrong to stand to resist the attackers. What he presents as the obstacle was his young age. He cites this reason to explain why he did not act and had to flee when his family property was looted or destroyed.

\section{FROM FOLK WISDOM}

TR8 also legitimates his action of fleeing from the attackers using a proverb that depicts a coward as playing safe instead of engaging them. The fact that he felt that he should not have allowed the family property to be stolen and he should have found a way to resist also portrays him as a man who only lacked the means to act like man.

\section{Excerpt 6}

R:Kwa sababu hata Waswahili walisema/ kwa muoga huenda kicheko /sasa afadhali huyu ametoroka amechekelewa ametoroka /lakini amejiokoa / Lakini sasa ukijaribu ukiangalia kama walijifanya hawakutoroka, pia nao wengi waliadhirika/unapata wenye walipoteza maisha yao/na sasa sisi wenye tulitoroka waoga tulichekelewa tu lakini tulirudi salama /wengi sasa ukiangalia saa hizi wamepata maalama/wameumia /wengine wamekufakufa /sasa hivyo afadhali mwenye alitoroka akaokoa maisha yake. Ee

R: Because even the Swahili said/ the home of the coward receives laughter / therefore the one who flees and is laughed at is better /but they have saved their lives/ But if you look at those who pretended and they never ran away / many were affected/ you find some who lost their lives/ but for us who fled as cowards we were only laughed at but we returned safely/ many of them if you check have marks/ they were injured/ some have died/ therefore the ones who fled and saved their lives are better.Yes (TR8P11).

The use of a proverb to justify his action of not standing to the attackers means that his reasoning widely recognized logic and he cannot therefore be challenged.

In the various responses presented above given by the displaced persons address psychological issues of blame even when the respondent is not asked to account for their actions. The respondents do not directly state that they 
and members of their group are not responsible for the violence. But in answering different questions the displaced persons also handle the business of attribution of responsibility for the violence and the loss that resulted. The strategies all share the common element that they are all calculated to give a version of events that presents them as not blameworthy.

\section{SOURCES OF FUNDING}

This research received no specific grant from any funding agency in the public, commercial, or not-for-profit sectors.

\section{CONFLICT OF INTEREST}

The author have declared that no competing interests exist.

\section{ACKNOWLEDGMENT}

None.

\section{REFERENCES}

[1] Aura R. (ed) (2010). Pursuing Justice for Sexual and Gender Based Violence in Kenya: Options for Protecting and compensating survivors of sexual and gender-based violence. Nairobi: Agency for Cooperation and Research in Development (ACORD). Last Accessed 25 March 2014 from www.acordinternational.org

[2] Edwards, D. Discursive Psychology in Fitch and Sanders (eds) Handbook of Language and Social Interaction (p257-273) Earlbum.

[3] Gutiérrez-Romero, R. (2010). The Role of Ethnic Identity and Economic Issues in the 2007 Kenyan Elections. University of Oxford, Department of International Development http://www.csae.ox.ac.uk/workingpapers

[4] Kanyinga, K. and Okello, D. ed (2010). Contradictions of Transition to Democracy in Fragmented Societies: The Kenya 2007 General Elections in Perspective in Kanyinga, K. and Okello, D. Tensions and Reversals in Democratic Transitions. The Kenya 2007 General Elections. (p1-28 Society for International Development (SID) and Institute for Development Studies (IDS), University of Nairobi

[5] Kimenyi, M. and Ndung'u, N. (n.d) Sporadic Ethnic Violence: Why Has Kenya Not Experienced a Full-Blown Civil War? http://www.irenkenya.com/ modules/articles/

[6] Klopp, J., Githinji,P and Karuoya, K. (2010). Internal Displacement and Local Peacebuilding in Kenya. Challenges and Innovations. Special Report. Washington: United States Institute of Peace.

[7] Matherson, I (undated). Kenya Six Months on: A New Beginning or Business as Usual?

[8] Briefing Papers. Minority Rights Group International. Accessed on 2 February 2015 from www.minorityrights.org

[9] Mukinda, F (2016) Police Plan to Recall Guns from Civilians after Licensing Scam. Daily Nation 7, February 2016.

[10] Roberts, J. (2009). Conflict Analysis of the 2007 Post-election Violence in Kenya. p.5. Accessed on 10 August 2014 from www.ndpmetrics.com

[11] Yieke, F. (2010). Ethnicity and Development in Kenya: Lessons from 2007 General Elections: Kenya Studies Review vol 3, 3, 5-1 